\title{
Hydroclimatic control of sediment and metal export from a rural catchment in northwestern Spain
}

\author{
L. Palleiro, M. L. Rodríguez-Blanco, M. M. Taboada-Castro, and M. T. Taboada-Castro \\ Facultade de Ciencias and Centro de Investigaciones Científicas Avanzadas (CICA), University of A Coruña, \\ Campus of A Coruña, 15071 A Coruña, Spain \\ Correspondence to: L. Palleiro (laura.palleiro@udc.es)
}

Received: 26 February 2014 - Published in Hydrol. Earth Syst. Sci. Discuss.: 1 April 2014

Revised: 29 July 2014 - Accepted: 7 August 2014 - Published: 18 September 2014

\begin{abstract}
This paper examines sediment and metal (Al, Fe, $\mathrm{Mn}, \mathrm{Cu}$, and $\mathrm{Zn}$ ) exportation at different timescales (annual, seasonal and event) during a 3-year period (2005-2008) in the Mero River headwater, a rural catchment under humid temperate climate. Interannual differences were found both in annual loads and their distributions throughout the year. At annual scale, sediment and particulate metal loads followed the same trend as streamflow, while dissolved metals showed different patterns. Runoff events contributed to $63 \%$ of the total sediment load, whereas particulate and dissolved loads in events accounted for between 38-61 and 27-49\%, respectively. Runoff events were characterized by high variability in sediment and metal loads, a few events representing a high percentage of the metal exported. Sediment loads were related to maximum and initial discharge. Particulate metal loads were highly correlated with sediment loads, runoff being the hydrological variable that best explains the load of these metals. Dissolved metal loads displayed different patterns. Dissolved Al, showed a great correlation with runoff, while dissolved Mn with maximum discharge.
\end{abstract}

\section{Introduction}

The understanding of the processes controlling sediment and metal export is critical to assessing and anticipating impacts on the water courses. Landscape characteristics of the catchment such as geology, slope, drainage and land use are important factors controlling the forms and quantities of sediments and metals that are transported to rivers (Miller et al., 2003; Kang et al., 2009). The transport mechanisms vary for each metal, depending on its abundance, solubility or distri- bution in particle size, among other factors (Horowitz et al., 1990; Park et al., 2007; Pokrovsky et al., 2010). Across the catchment, sediment and metal delivery can also change due to several factors such as the localization or its connectivity with the river (Rodríguez-Blanco et al., 2010a).

Contamination from non-point sources is difficult to quantify because it is caused by a variety of natural and anthropogenic sources. In particular, possible sources of metal pollution to rural catchments are domestic wastewaters, atmospheric deposition, soil erosion, and agricultural and livestock activities. Runoff from agricultural soils could be a relevant factor in metal transfer to watercourses when fertilization and slurry application is relatively frequent because metals are commonly present in such fertilizers (L'Herroux et al., 1997; Xue et al., 2000; Taboada-Castro et al., 2012). Erosion processes within a catchment are responsible for sediment transfers to water courses. In turn, metal transport may be dominated by sediments, since metals are mostly adsorbed on sediment particles, as reported in several studies (Horowitz et al., 1990; Miller et al., 2003).

Rainfall-runoff events have often been the main culprit causing changes in sediment and metal transport (Xue et al., 2000; Miller et al., 2003; Rodríguez-Blanco et al., 2009, $2010 \mathrm{~b})$. So, temporal data of sediments and metals obtained with an adequate sampling frequency during rainfall-runoff events are essential for reliable annual element transport estimates and model development. These data are also important for understanding the mechanisms controlling sediment and metal concentrations in rivers and for the design of research and monitoring programs. Factors affecting sediment transport are now better known, however, processes governing metal concentrations in rivers and streams remain 
relatively poorly understood, despite the importance of metals for aquatic ecosystems. Rainfall-runoff events were monitored in metallogenic (Cánovas et al., 2008), urban (McPherson et al., 2005) and agricultural areas (Xue et al., 2000), as well as in forest landscapes with serious problems of soil acidification (Borg and Johansson, 1989). However, rural catchment studies focusing on factors affecting metal loads during rainfall-runoff events are limited and most studies have not taken into account both hydrological and meteorological parameters, even though these are important for metal exportation. For instance, Miller et al. (2003) associated high metal loads with high discharge in two agricultural catchments, while Kang et al. (2009) associated said loads with an increase in both rainfall during the events and antecedent rainfall in the inlet and the outlet of an urban catchment.

In humid areas of Spain, studies on metal loads at catchment scale are scarce and most focus on metal transference to estuarine systems, such as that by Álvarez-Iglesias et al. (2006). However, metal transport to the fluvial system during runoff events in rural environments has only been addressed considering few events (Taboada-Castro et al., 2002; Rodríguez-Blanco et al., 2009; Palleiro et al., 2012), making it difficult to perceive any existing metal patterns.

The objective of this study is to understand hydroclimatic factors affecting the transport of sediments and metals (dissolved and particulate) from an agroforestry catchment to a river. An analysis of temporal variability in sediment and metal transport at different timescales (annual, seasonal and event) was carried out. Five metals ( $\mathrm{Al}, \mathrm{Fe}, \mathrm{Mn}, \mathrm{Cu}, \mathrm{Zn}$ ) and sediments were monitored at the Mero River headwater (NW Spain), the main river supplying water to the city of A Coruña (450 000 inhabitants). This study is particularly interesting because sediment and metals introduced into the river can also accumulate on the riverbed and in sediment layers of a reservoir located downstream of the Mero River, becoming a potential source of metal pollution. This research provides a data set of great importance to develop empirical models. Such models could be used to predict suspended sediment and metal export of the catchment from routine programs of water-quality monitoring.

\section{Study area}

The study was conducted in the Mero headwater, a catchment of $65 \mathrm{~km}^{2}$, located upstream from the city of A Coruña in the northwest part of the Iberian Peninsula (Fig 1, UTM coordinates $4784798^{\circ} \mathrm{N}, 561919^{\circ} \mathrm{W}$; European 1950 datum zone $29^{\circ} \mathrm{N}$ ). The Mero headwater is a fourth-order catchment with an altitude ranging from 60 to $490 \mathrm{~m}$ a.s.l. with a mean slope of $15 \%$. The stream length is $27 \mathrm{~km}$ and the mean stream slope gradient is $1 \%$. The geology is uniform across the site, comprised by basic metamorphic schists of the Órdenes Complex formation. The main soil types are classified as Umbrisols and Cambisols (FAO, 2006). They are relatively deep, and characterized by acidic $\mathrm{pH}$ (mean: 5.6; range: 4.7-6.3), loam, silt-loam or clay-loam textures with high content of organic matter (mean $9.0 \%$; range 2.8 $19.3 \%$ ). The order of abundance of the five metals studied in the weathered bedrock is as follows: $\mathrm{Al}>\mathrm{Fe}>\mathrm{Mn}>\mathrm{Zn}>\mathrm{Cu}$ (Guitián et al., 1992). The catchment land cover is representative of a rural area and consists of a mixture of forest $(53 \%)$, agricultural fields $(42 \%)$ and some impervious areas (5\%), all of them equally distributed across the catchment. Agricultural areas are dominated by pastures (38\% of total area), the remaining agricultural area $(4 \%)$ is dedicated to maize and winter cereals.

The area's climate is humid temperate. Mean-annual temperature is $13{ }^{\circ} \mathrm{C}$, with the mean minimum and maximum temperatures occurring in January $\left(8^{\circ} \mathrm{C}\right)$ and August $\left(19^{\circ} \mathrm{C}\right)$, respectively. Mean-annual rainfall is $1100 \mathrm{~mm}(1983-2008)$ and it is usually concentrated in autumn and winter (66\%). Consequently, most events occurred in autumn (26) and winter (17) followed by spring (4) and summer (3). The mean event rainfall was $39.9 \mathrm{~mm}$, ranging from 12.4 to $101.5 \mathrm{~mm}$. Peak discharge ranged from 0.4 to $21.2 \mathrm{~m}^{3} \mathrm{~s}^{-1}$; the maximum increase of discharge (peak discharge/ discharge at the beginning of the runoff event) being 6.3. The mean discharge of the 50 events was $1.7 \mathrm{~m}^{3} \mathrm{~s}^{-1}$. A detailed study of the hydrological behavior of this catchment can be found in Palleiro et al. (2014).

\section{Material and methods}

\subsection{Data collection}

Rainfall data were obtained from three recording tipping bucket rainfall gauges (precision of $0.2 \mathrm{~mm}$ ) at $10 \mathrm{~min}$ intervals. Mean rainfall was determined using the reciprocal distance squared method. Stream level was monitored continuously (logged at $10 \mathrm{~min}$ intervals) using a differential pressure transducer sensor (ISCO 720) connected to an autosampler (ISCO 6712-FS) at the catchment outlet (Fig. 1), where water samples were collected from October 2005 to September 2008. The sampling site was located at the midpoint of the channel cross section. The inlet of the automatic sampler tube remained at about $1 \mathrm{~m}$ from the riverbed. A total of 753 water samples was collected during the study period. Water samples were taken manually during baseflow conditions on a biweekly basis and using the automatic sampler during runoff events. The sampler was programmed to begin sampling with increases of $2-3 \mathrm{~cm}$ above the water level at the beginning of each rainfall event. Sampling frequency was also programmed to take samples during short time intervals $(2-8 \mathrm{~h})$ providing samples during rising and recession limbs of the hydrograph to give representative values of sediment and metal transport during the studied events. 


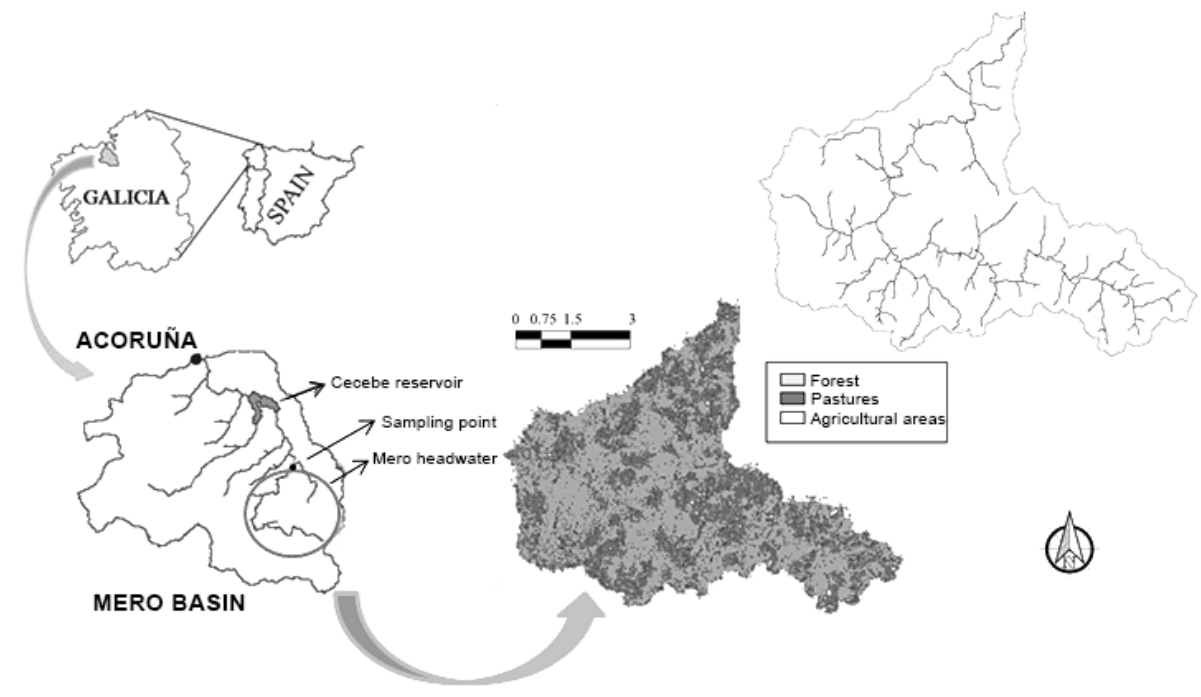

Figure 1. Site location, land use and drainage network of the Mero catchment.

To avoid contamination all polyethylene sampling bottles were carefully sunk in a $10 \%$ solution of $\mathrm{HNO}_{3}$ for at least $24 \mathrm{~h}$, then rinsed four times with Milli-Q water.

\subsection{Chemical analysis}

Sediment concentrations were determined gravimetrically by passing the water samples through filters $(0.45 \mu \mathrm{m})$ using a vacuum-operated-filtration system and the residue was ovendried at $105^{\circ} \mathrm{C}$ for $24 \mathrm{~h}$. The weight of each dried residue and the sample volume provided the sediment concentration.

Five metal species ( $\mathrm{Al}, \mathrm{Fe}, \mathrm{Mn}, \mathrm{Cu}$, and $\mathrm{Zn}$ ) were analyzed. Total and dissolved metals were measured with a thermoelectron high-resolution magnetic sector field ICP-MS Element XR. Total concentrations were determined after digesting $50 \mathrm{~mL}$ of subsamples acidified with ultra-high purity acids, $1 \mathrm{~mL}$ of $\mathrm{HNO}_{3}$ and $3 \mathrm{~mL}$ of $\mathrm{HCl}$, in a block of graphite. The dissolved contents were determined after passing samples through $0.45 \mu \mathrm{m}$ filters which were acidified to a $\mathrm{pH}$ lower than 2. Particulate concentrations were calculated from the difference between total and dissolved concentrations. Particulate and dissolved concentrations were represented with a suffix "P" or "D", respectively, after each metal. The external reproducibility of chemical preparation and ICP measurements were performed on three replicate samples resulting in standard deviations lower than $3 \%$ for total metal and less than $4 \%$ for dissolved metals except for $\mathrm{Zn}$ whose standard deviation was below $8 \%$. The accuracy and analytical precision have been checked by the analysis of a multielemental standard solution from Sigma-Aldrich (Fluka number 51844) and duplicate samples in each analytical set; recovery percentages were above $80 \%$ for all analyzed metals.

\subsection{Characteristics of rainfall-runoff events}

Not all events were analyzed in this paper, just the ones showing a discharge increase exceeding 1.5 times the discharge at the start of the event. This criterion allowed us to identify 50 rainfall-runoff events during the entire monitoring period. Hydrographs of runoff events were separated into two components (direct or quick runoff and baseflow) using a digital filter (Arnold et al., 1995). Sediment and metal loads were determined by summing up the products of mean concentrations of two consecutive samples and the total discharge volumes between the times of sampling. Direct runoff load was calculated by subtracting the event-baseflow load from the total load (direct runoff + baseflow). Missing data were minimal (only two rainfall-runoff events during the study period) and because of that the data were representative to estimate the catchment exportation.

The rainfall-runoff events were characterized by four groups of variables: antecedent conditions to the event, rainfall causing the event, discharge during the event, and sediment and metal loads during the event. Antecedent conditions are described by accumulated rainfall 1, 3, 5, 7, 15 and 21 days before the event (AP1d, AP3d, AP5d, AP7d, AP15d and AP21d, respectively, mm) and baseflow $\left(Q_{\mathrm{b}}, \mathrm{m}^{3} \mathrm{~s}^{-1}\right)$, which is the discharge before the event. Rainfall that caused the event is characterized by rainfall $(P, \mathrm{~mm})$, mean rainfall intensity $\left(I_{\text {mean }}, \mathrm{mm} \mathrm{h}^{-1}\right)$ and maximum rainfall intensity $\left(I_{\max }, \mathrm{mm} \mathrm{h}^{-1}\right)$. The discharge variables included: runoff $(R, \mathrm{~mm})$, the mean and maximum discharge $\left(Q_{\text {mean }}, \mathrm{m}^{3} \mathrm{~s}^{-1}\right.$ and $Q_{\max }, \mathrm{m}^{3} \mathrm{~s}^{-1}$, respectively) and the relationship between this maximum discharge and baseflow $\left(Q_{\max } / Q_{\mathrm{b}}\right)$. The last group of variables includes sediment and metal loads during the events. 
Before calculating sediment and metal loads at annual and seasonal scales, data sets were generated at monthly steps.

\subsection{Statistical analysis}

The normality of data was analyzed using a Shapiro-Wilk test. Data without a normal distribution were log transformed in order to apply parametric statistics. At annual scale, sediment and metal exportation of the Mero River was compared with that of other catchments using a test $t$. At seasonal scale, variances were compared using an ANOVA (analysis of variance) test to investigate whether there are significant differences in the sediment and metal loads among seasons. Then, in order to know between which seasons there were significant differences, a Tukey test was applied. In addition, at seasonal and event scales, the Pearson product-moment correlation was applied to assess the magnitude of the relationship between meteorological and hydrological variables with sediment and metal loads. At event scale, a stepwise multiple-regressions technique was used to improve the variance of metal and sediment loads explained by meteorological and hydrological variables. All statistical analyses were performed using the $\mathrm{R}$ program.

\section{Results and discussion}

\subsection{Annual sediment and metal export}

Table 1 shows values of rainfall, streamflow, sediment and metal exportation during the study period. All metals exist predominantly in particulate form, representing 98, 97, 97, 70 and $83 \%$ for $\mathrm{Al}, \mathrm{Fe}, \mathrm{Mn}, \mathrm{Cu}$ and $\mathrm{Zn}$, respectively. This suggests that the transport of these metals is linked to particle transport, as found by Miller et al. (2003) in two agricultural catchments. Particulate metals were exported during all hydrological years in the following order: $\mathrm{Fe}>\mathrm{Al}>\mathrm{Mn}>\mathrm{Zn}>\mathrm{Cu}$. This order of exportation is similar to that of weathered bedrock, except in the cases of Fe and $\mathrm{Al}$, whose orders of abundance in water were reversed. This is justified by the low Al solubility in the weathering processes in spite of its abundance in soils and rocks (Exley, 2003). In general, dissolved metals were exported in the same order as in particulate form.

The catchment showed interannual variability in sediment and metal exportation during the study period, exportation during the hydrological year 2006/07 being almost threefold higher for sediments and twofold higher for particulate metals than in 2007/08. Both maximum sediment and particulate metal exports occurred when rainfall and streamflow were maximum (Table 1) and minimum exportation occurred when rainfall and streamflow were low, although the increase in streamflow did not show the same increase in sediment and metal exportation. This reflects that other factors are affecting sediment and particulate metal exportation. Thus, Ollivier et al. (2011) reported interannual differences in particu-
Table 1. Values of annual rainfall, streamflow, sediment and metal exportation for 3 hydrological years. Sediment export is in megagrams per square kilometer $\left(\mathrm{Mg} \mathrm{km}^{-2}\right)$ and metal exports are in kilograms per square kilometer $\left(\mathrm{kg} \mathrm{km}^{-2}\right)$.

\begin{tabular}{lllll}
\hline & $2005 / 06$ & $2006 / 07$ & $2007 / 08$ & $\mathrm{CV}(\%)$ \\
\hline Rainfall (mm) & 1222 & 1840 & 1131 & 26 \\
Streamflow (mm) & 423 & 629 & 264 & 42 \\
Sediment & 11.4 & 14.9 & 5.3 & 6 \\
$\mathrm{Al}_{\mathrm{P}}$ & 376 & 422 & 160 & 44 \\
$\mathrm{Al}$ & 5.5 & 7.9 & 5.1 & 24 \\
$\mathrm{Fe}_{\mathrm{P}}$ & 414 & 477 & 193 & 41 \\
$\mathrm{Fe}_{\mathrm{D}}$ & 10.9 & 10.6 & 15.9 & 24 \\
$\mathrm{Mn}_{P}$ & 17.3 & 19.9 & 9.1 & 37 \\
$\mathrm{Mn}_{\mathrm{D}}$ & 0.3 & 0.3 & 0.7 & 58 \\
$\mathrm{Cu}$ & 0.4 & 0.4 & 0.2 & 38 \\
$\mathrm{Cu}$ & 0.2 & 0.2 & 0.1 & 58 \\
$\mathrm{Zn}_{\mathrm{P}}$ & 1.4 & 2.4 & 1.0 & 45 \\
$\mathrm{Zn}_{\mathrm{D}}$ & 0.4 & 0.3 & 0.3 & 19 \\
\hline
\end{tabular}

Note: $\mathrm{p}$ : particulate form; $\mathrm{D}$ : dissolved form; $\mathrm{CV}$ : coefficient of variation.

late element exportation associated with the amount and distribution of rainfall-runoff events, while Rodríguez-Blanco et al. (2010a, b) and Taboada-Castro et al. (2010), in an agroforestry catchment next to the Mero River, related sediment exportation variability to rainfall distribution, streamflow and vegetation cover extent, as well as with the level of connectivity between agricultural land (main source of sediments) and stream.

Dissolved metal exportation showed a less pronounced interannual variability than particulate metals and did not show a clear relation with streamflow except $\mathrm{Al}_{\mathrm{D}}$, which increased with streamflow as its particulate form. This could be attributed to an increase of a microparticulate component during the years of higher streamflow. By contrast, the $\mathrm{Fe}_{\mathrm{D}}$ and $\mathrm{Mn}_{\mathrm{D}}$ load was higher in 2007/08, which was the driest year and with lesser streamflow but higher baseflow (Palleiro et al., 2014). Since the catchment lacks significant sources of pollution, it is likely that these dissolved metals are present in groundwater, with longer residence time in rocks and soils than the surface water, and thus, with a higher power of weathering (Nagano et al., 2003; Navrátil et al., 2007).

The mean-annual sediment and metal exportation to the Mero River were compared with those of other catchments with agroforestry land uses, in which the same method of load calculation as in this work was used (Table 2). Sediment export is similar to that of the Corbeira catchment in NW Spain (Rodríguez-Blanco et al., 2010a) and it is higher than that obtained by Bull (1997) for a forest catchment in the UK $(p<0.05)$, but it is lower than that reported by Walling et al. (1997) in the Dart catchment $(p<0.05)$ where sediments come from surface erosion of the steep slopes of both pasture areas and cultivated areas by the exposure of bare soils. The low surface runoff (Palleiro et al., 2014) together with the 
Table 2. Mean-annual sediment (SS; $\left.\mathrm{Mg} \mathrm{km}^{-2}\right)$ and metal $\left(\mathrm{kg} \mathrm{km}^{-2}\right)$ exportation for the Mero River and other catchments.

\begin{tabular}{llllllllllll}
\hline & $\mathrm{SS}$ & $\mathrm{Al}$ & $\mathrm{Fe}$ & $\mathrm{Mn}$ & $\mathrm{CuP}$ & $\mathrm{Zn}$ & $\mathrm{Al} l_{\mathrm{D}}$ & $\mathrm{Fe}_{\mathrm{D}}$ & $\mathrm{Mn}_{\mathrm{D}}$ & $\mathrm{Cu}_{\mathrm{D}}$ & $\mathrm{Zn}_{\mathrm{D}}$ \\
\hline Mero River & 10.5 & 319 & 361 & 15.4 & 0.3 & 1.6 & 6.2 & 12.5 & 0.4 & 0.1 & 0.3 \\
$\begin{array}{l}\text { Bull (1997) } \\
\text { Walling et al. (1997) }\end{array}$ & $0.7-0.8$ & & & & & & & & & & \\
$\begin{array}{l}\text { Rodríguez-Blanco et al. (2010a) } \\
\text { Soto-Varela et al. (2014a) }\end{array}$ & 8.3 & & & & & & & & & \\
\end{tabular}

Note: $\mathrm{P}$ : particulate form; $\mathrm{D}$ : dissolved form.

scarce proportion of agricultural areas well-connected to the river (Rodríguez-Blanco et al., 2013) probably limited the sediment exportation in the Mero catchment in relation to the Dart catchment.

The mean-annual metal export is similar to that reported by Soto-Varela et al. (2014a) in the Corbeira catchment $(p<0.05)$, an agroforestry catchment $\left(16 \mathrm{~km}^{2}\right)$ adjacent to the study site, also located in the area of schists of the Órdenes Complex.

\subsection{Seasonal sediment and metal loads}

Figure 2 shows seasonal streamflow, sediment and metal loads for the study period. Sediment presented different seasonal patterns during these 3 years. Thus, 2005/06 and 2006/07 showed the highest sediment transport in autumn, 46 and $67 \%$, respectively, while during 2007/08 the maximum occurred in spring $(76 \%)$. The high rainfall amount recorded in the first two autumns $(536,936 \mathrm{~mm})$ in relation to the third autumn $(123 \mathrm{~mm})$ as well as the high amount of rainfall registered in spring 2007/08 (381 mm) vs. spring 2005/06 $(93 \mathrm{~mm})$ and 2006/07 $(213 \mathrm{~mm})$ could explain these differences. Visual observations performed in the study catchment showed that high sediment transport occurs when rainfall amount is high and vegetation cover scarce, which is frequent in autumn and spring, coinciding with maize harvesting and preparation for sowing, respectively. This was also reported by Rodríguez-Blanco et al. $(2010 \mathrm{~b}, \mathrm{c})$ for an area near the Mero River, where they found that high sediment loads were transported in autumn after the development of rills and ephemeral gullies in some agricultural fields that were well-connected with the drainage system after maize harvesting.

The ANOVA revealed significant differences in sediment loads among seasons and the Tukey test indicated that sediment loads in autumn and winter were significantly higher than in summer $(p<0.05)$, similarly to what happened with rainfall and streamflow. In fact, sediment transport was significantly related to rainfall $(r=0.78 ; p<0.01)$ and streamflow $(r=0.85 ; p<0.01)$.

Particulate metal loads showed the same seasonal trend as sediment (Fig. 2) and were also positively and significantly correlated with rainfall ( $r$ ranged from 0.66 for $\mathrm{Zn}_{\mathrm{P}}$ to 0.79

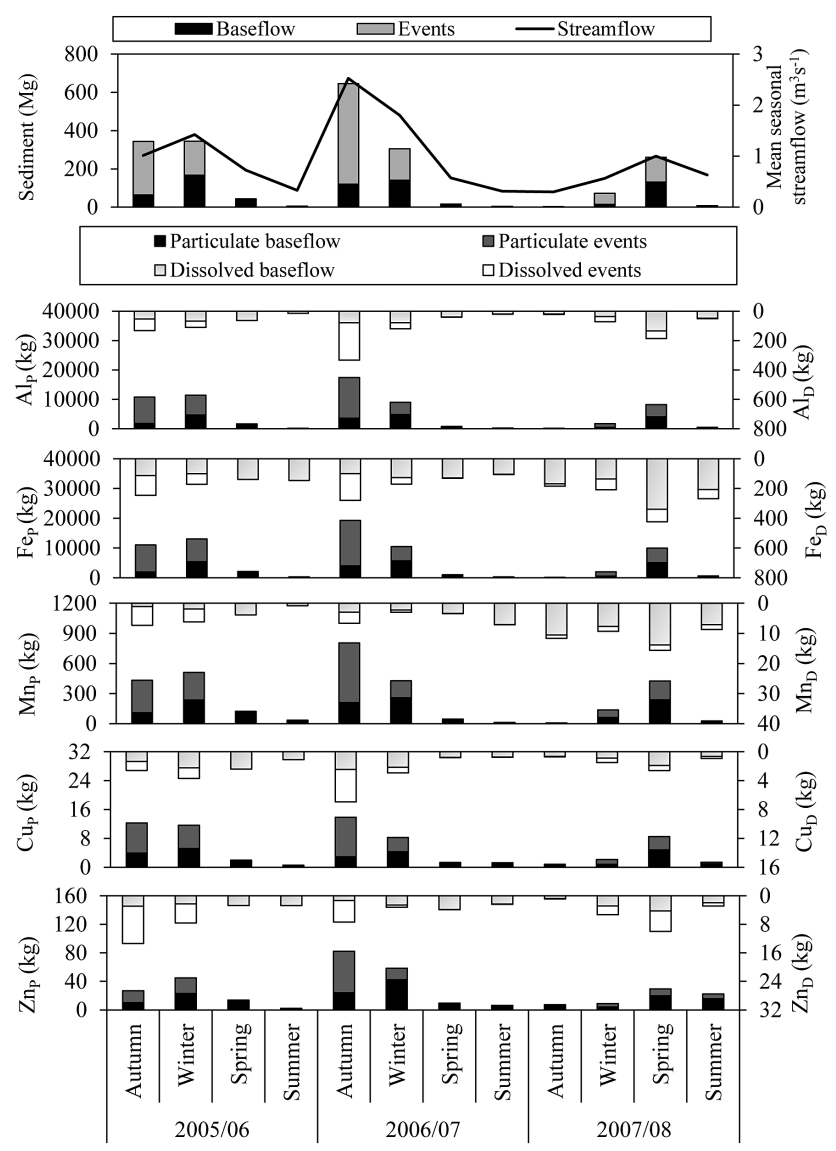

Figure 2. Seasonal streamflow (mean), sediment and metal loads.

for $\left.\mathrm{Mn}_{\mathrm{P}} ; p<0.01\right)$ and streamflow ( $r$ ranged from 0.80 for $\mathrm{Cu}_{\mathrm{P}}$ to 0.94 for $\left.\mathrm{Zn}_{\mathrm{P}} ; p<0.01\right)$. The Tukey test also demonstrated that all particulate metals presented higher exportations in autumn and winter than in summer $(p<0.05)$.

In dissolved form, $\mathrm{Al}_{\mathrm{D}}$ and $\mathrm{Cu}_{\mathrm{D}}$ loads followed a similar pattern to that of their particulate form and were higher in autumn than in summer $(p<0.05)$. Both metals were positively and significantly associated with rainfall $\left(r=0.81\right.$ for $\mathrm{Al}_{\mathrm{D}}$; $r=0.76$ for $\left.\mathrm{Cu}_{\mathrm{D}} ; p<0.01\right)$ and streamflow $(r=0.83$ for $\mathrm{Al}_{\mathrm{D}} ; r=0.89$ for $\left.\mathrm{Cu}_{\mathrm{D}} ; p<0.01\right)$. The fact that $\mathrm{Al}_{\mathrm{D}}$ and $\mathrm{Cu}_{\mathrm{D}}$ follow the same distribution as that of their particulate form can reflect the presence of these metals in colloidal forms, 
such as it was observed by Sigg et al. (2000), since in this study $0.45 \mu \mathrm{m}$ filters were used. $\mathrm{Fe}_{\mathrm{D}}, \mathrm{Mn}_{\mathrm{D}}$ and $\mathrm{Zn}_{\mathrm{D}}$ loads did not show seasonal patterns. Differences in seasonal exportation of dissolved metals were also obtained by Pokrovsky et al. (2010), who related these to the different sources and characteristics of each metal.

\subsection{Contribution of runoff events to total sediment and metal loads}

Contributions of rainfall-runoff events to sediment and metal exportation are presented in Fig. 3. Most of the sediment and metal loads was exported in a short period of time, because all events happened in only 100 days, i.e., less than onetenth of the study period. Events contributed to $63 \%$ of the total sediment load. For the particulate metals the contribution of events was $38-61 \%$, in this order: $\mathrm{Zn}_{\mathrm{P}}<\mathrm{Mn}_{\mathrm{P}}<\mathrm{Cu}_{\mathrm{P}}$ $<\mathrm{Fe}_{\mathrm{P}}<\mathrm{Al}_{\mathrm{P}}$. Only the $\mathrm{Zn}_{\mathrm{P}}$ load was higher in baseflow than during events. The major contribution of events to $\mathrm{Al}_{\mathrm{P}}$ and $\mathrm{Fe}_{\mathrm{P}}$ exportations seemed logical since these elements are especially abundant in the soils of the catchment (Guitián et al., 1992) and, therefore, very susceptible to erosion and transport.

Dissolved loads during events accounted for $27-49 \%$ of the load, following this sequence: $\mathrm{Fe}_{\mathrm{D}}<\mathrm{Cu}_{\mathrm{D}}<\mathrm{Mn}_{\mathrm{D}}<\mathrm{Al}_{\mathrm{D}}<\mathrm{Zn} \mathrm{n}_{\mathrm{D}}$. This indicates that dissolved metal transport is mainly associated with baseflow, while the transport of most of the particulate metal is mainly related to runoff events. The order of contribution of dissolved metal in relation to particulate metal is reversed because several factors are affecting metal solubility and the effect of these factors may be different for each metal. For instance, some metals have more affinity to form complexes with organic matter, while others can be adsorbed onto oxides of $\mathrm{Fe}$ and $\mathrm{Mn}$ or to colloid forms which pass through the filter (Förstner and Wittmann, 1981). The strong trend of $\mathrm{Cu}_{\mathrm{D}}$ and $\mathrm{Fe}_{\mathrm{D}}$ transported during baseflow could be related to their affinity to form complexes with organic matter (Förstner and Wittmann, 1981; Xue et al., 2000; Park et al., 2007), which facilitates their transport in dissolved phase as found by Soto-Varela et al. (2014b) in the confluence of the Corbeira catchment (catchment with similar characteristics to the studied catchment) with the Mero River. The major contribution of events to $\mathrm{Zn}_{\mathrm{D}}$ exportation vs. $\mathrm{Al}_{\mathrm{D}}, \mathrm{Fe}_{\mathrm{D}}$ and $\mathrm{Mn}_{\mathrm{D}}$ could be due to the higher solubility of $\mathrm{Zn}$. On the other hand, $\mathrm{Zn}$ is more abundant in soils, but it is more retained than $\mathrm{Cu}$ (Adriano, 2001), hence, the transport of $Z n_{D}$ is favored when runoff processes are active. The $Z n_{D}$ is delivered to the river probably by subsurface flow, which is the dominant runoff process in this catchment (Palleiro et al., 2014).

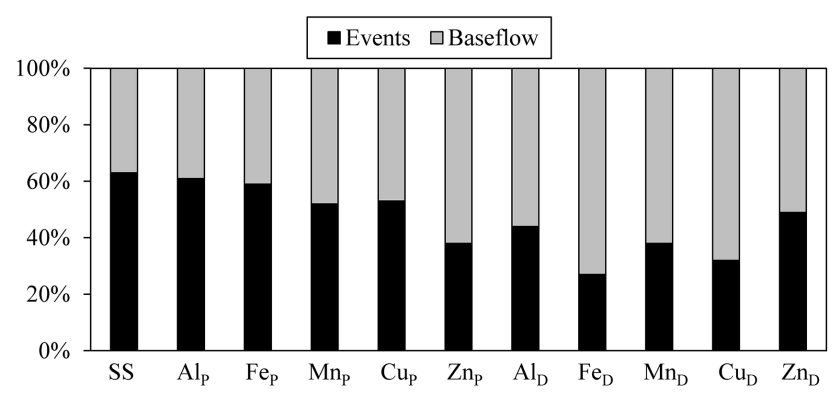

Figure 3. Fractions of sediment (SS), particulate and dissolved metals transported during runoff events and baseflow conditions during the study period. $\mathrm{P}$ : particulate form; $\mathrm{D}$ : dissolved form.

\subsection{Sediment, particulate and dissolved metal loads in runoff events}

Sediment and total metal loads between runoff events were highly variable. Sediment load ranged between less than 0.1 and $118 \mathrm{Mg}$, with a mean of $20 \mathrm{Mg}$, although only three events transported more than $60 \mathrm{Mg}$. In the case of metals, both maximum particulate and dissolved metal loads were 2 orders of magnitude higher than minimum loads (Table 3 ). For instance, $\mathrm{Al}_{\mathrm{P}}$ and $\mathrm{Fe}_{\mathrm{P}}$ loads ranged between less than 1 and $4500 \mathrm{~kg}$. Mean values were both near $600 \mathrm{~kg}$, but only four events transported loads surpassing $2000 \mathrm{~kg}$. The above results indicate that there are a few events with very high loads, so, only a few events are responsible for the high percentage of sediment and metal exportation during events (Fig. 4). In fact, more than $80 \%$ of the sediment load and more than $75 \%$ of the metals are transported in less than half of the duration of all the events. For all particulate metals, only 15 of the 50 events analyzed transported about $82 \%$ of the load. Dissolved metal loads presented more differences among them than particulate. Thus, 15 events exported 74, $66,85,74$ and $87 \%$ of $\mathrm{Al}_{\mathrm{D}}, \mathrm{Fe}_{\mathrm{D}}, \mathrm{Mn}_{\mathrm{D}}, \mathrm{Cu}_{\mathrm{D}}$ and $\mathrm{Zn}_{\mathrm{D}}$, respectively. Several authors reported similar behavior for sediment and metal exportations during events (Xue et al., 2000; Rodríguez-Blanco et al., 2010b). In the catchment studied, there were several examples of events with high contribution to the annual load. The most extreme case was for $\mathrm{Mn}_{\mathrm{D}}$. One event occurring on 2-3 November 2005 exported $5.2 \mathrm{~kg}$ of $\mathrm{Mn}_{\mathrm{D}}$, representing $0.1 \mathrm{~kg} \mathrm{~km}^{-2}$ and $27 \%$ of $\mathrm{Mn}_{\mathrm{D}}$ exported during that hydrological year. This event was generated with a rainfall of $52.8 \mathrm{~mm}$ after two consecutive events. As a consequence of previous rainfall, this event showed a runoff value of $2.2 \mathrm{~mm}$ (slightly higher than the mean of $2.0 \mathrm{~mm}$ ) and a notable increase in discharge $\left(Q_{\max } / Q_{\mathrm{b}}=5.5\right)$. This event also corresponded with the highest loads of $\mathrm{Al}_{\mathrm{P}}, \mathrm{Fe}_{\mathrm{P}}$, $\mathrm{Mn}_{\mathrm{P}}$ and $\mathrm{Fe}_{\mathrm{D}}$, representing 19, 16, 14 and $4 \%$ of the annual exportation, respectively. The exportation of the mentioned particulate metals was linked with sediment exportation, although this event did not show the highest sediment load. Sometimes this is attributed to particle size. It is well 
Table 3. Values for discharge, runoff, sediment $(\mathrm{Mg})$ and metal loads $(\mathrm{kg})$ during the 50 rainfall-runoff events analyzed.

\begin{tabular}{lrrrr}
\hline & Mean & Minimum & Maximum & $\mathrm{CV}$ \\
\hline$Q_{\text {mean }}\left(\mathrm{m}^{3} \mathrm{~s}^{-1}\right)$ & 1.7 & 0.3 & 11.0 & 117 \\
$R(\mathrm{~mm})$ & 2.0 & 0.1 & 24.6 & 202 \\
Sediment & 20 & $<0.1$ & 118.4 & 139 \\
$\mathrm{Al}$ & 594.6 & 0.3 & 4671.2 & 151 \\
$\mathrm{Fe}$ & 654.7 & 0.7 & 4356.1 & 144 \\
$\mathrm{Mn}$ & 23.4 & $<0.1$ & 158.0 & 136 \\
$\mathrm{Cu}$ & 0.5 & $<0.1$ & 3.4 & 148 \\
$\mathrm{Zn}_{\mathrm{P}}$ & 1.5 & $<0.1$ & 9.2 & 143 \\
$\mathrm{Al}$ & 7.2 & $<0.1$ & 36.9 & 117 \\
$\mathrm{Fe}_{\mathrm{D}}$ & 7.5 & 0.1 & 27.7 & 93 \\
$\mathrm{Mn}_{\mathrm{D}}$ & 0.2 & $<0.1$ & 5.2 & 329 \\
$\mathrm{Cu}_{\mathrm{D}}$ & 0.1 & $<0.1$ & 0.8 & 134 \\
$\mathrm{Zn}_{\mathrm{D}}$ & 0.5 & $<0.1$ & 4.4 & 178 \\
\hline
\end{tabular}

Note: $\mathrm{p}$ : particulate form; $\mathrm{D}$ : dissolved form; $\mathrm{CV}$ : coefficient of variation.

recognized that small particles or coarse particles with coatings of oxides or organic matter usually contain high concentrations of metals as reported Devesa-Rey et al. (2011) when they analyzed bed sediments in a rural catchment of NW Spain, or by Horowitz et al. (1990) when they analyzed metal concentrations in suspended sediments of six rivers in the USA. However, it does not seem to be the cause of the high $\mathrm{Al}_{\mathrm{P}}, \mathrm{Fe}_{\mathrm{P}}$, and $\mathrm{Mn}_{\mathrm{P}}$ exportation because this event yielded a high sediment concentration. Visual surveys showed a strong laminar erosion as well as the formation of rills and ephemeral gullies in some agricultural fields of the Corbeira catchment (Rodríguez-Blanco et al., 2010c), adjacent to the Mero catchment. It is probable that this could also happen in the Mero catchment because both basins have similar characteristics.

The event of 7-10 December 2006 was produced by a high rainfall amount $(101.5 \mathrm{~mm})$ under wetness conditions $(\mathrm{AP} 15 \mathrm{~d}=290.4 \mathrm{~mm})$, which generated the highest runoff volume $(24.9 \mathrm{~mm})$ observed in the catchment (Palleiro et al., 2014). This event showed the highest $\mathrm{Al}_{\mathrm{D}}$ and $\mathrm{Cu}_{\mathrm{D}}$ loads (about $6.5 \%$ of annual loads). $\mathrm{Cu}_{\mathrm{D}}$ exportation was $0.1 \mathrm{~kg} \mathrm{~km}^{-2}$, a value similar to that of $\mathrm{Cu}_{\mathrm{D}}$ load transported during all events of 2007/08.

The above examples illustrate significant differences in metal loads among events, as frequently demonstrated in rural areas (Kang et al., 2009; Rodríguez-Blanco et al., 2009).

The percentage of dissolved and particulate metals also varied from one event to another. $\mathrm{Al}_{\mathrm{P}}, \mathrm{Fe}_{\mathrm{P}}$ and $\mathrm{Mn}_{\mathrm{P}}$ reached mean values of about $95 \%$. $\mathrm{Cu}$ and $\mathrm{Zn}$ were also dominated by the particulate phase (about $68 \%$ ). The predominance of the particulate fraction during events agrees with that observed by Nagano et al. (2003) in a rural catchment in Japan and by Xue et al. (2000) in an agricultural catchment in Switzerland.
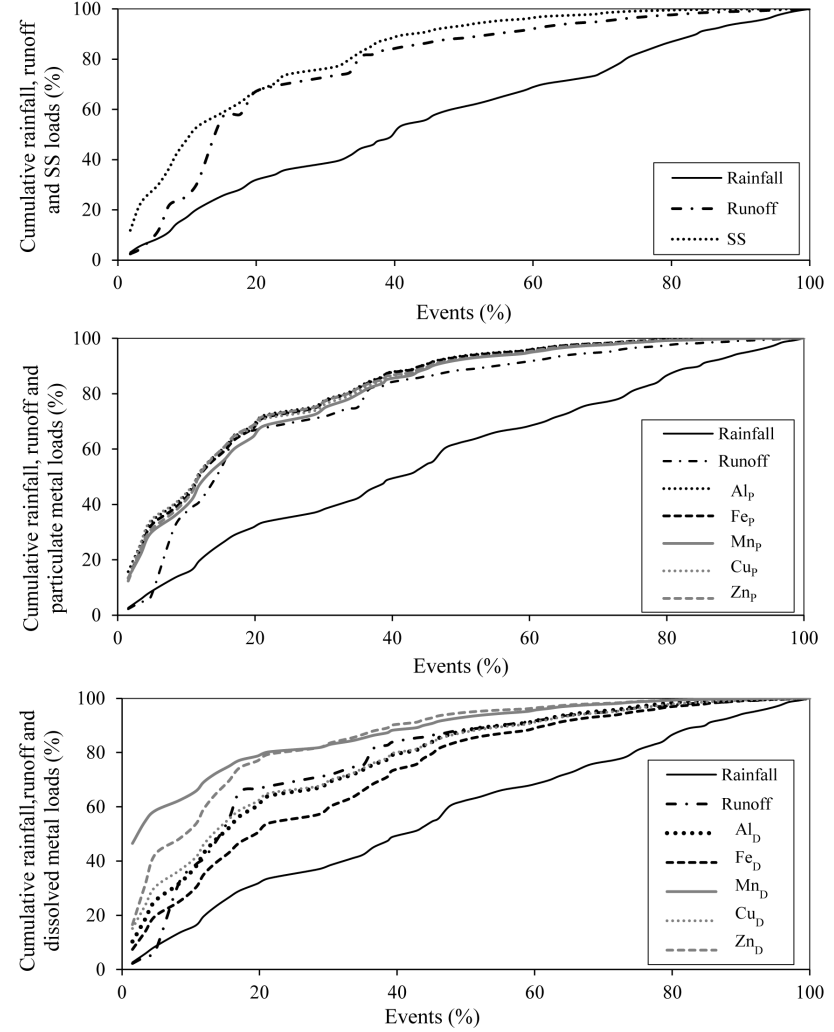

Figure 4. Cumulative rainfall, runoff, SS and metal loads during events. Events were ranked according to decreasing sediment and metal loads. $\mathrm{P}$ : particulate form; $\mathrm{D}$ : dissolved form.

Metal characteristics are also involved in the distribution between particulate and dissolved fractions. Thus, $\mathrm{Al}, \mathrm{Fe}$ and $\mathrm{Mn}$ are abundant in earth's crust and relatively insoluble under oxidizing conditions in surface water (Förstner and Wittmann, 1981). Because of this, they are strongly dominated by the particulate phase while $\mathrm{Cu}$ and $\mathrm{Zn}$ are less abundant in natural environments and have high affinity for chelation to organic ligands, which favors their presence in the dissolved phase (Xue et al., 2000; Aldrich et al., 2002; Miller et al., 2003).

\subsection{Factors affecting sediment and metal loads during rainfall-runoff events}

To analyze factors that control sediment and metal loads during rainfall-runoff events, a Pearson correlation matrix was done including several meteorological and hydrological variables with sediment, particulate and dissolved metal loads (Table 4). Sediment load was well correlated with all analyzed variables except mean rainfall intensity, which is not a relevant variable for the hydrological response in the region (Rodríguez-Blanco et al., 2012; Palleiro et al., 2014). The best relationship was observed with runoff and maximum discharge, since these variables are linked with sediment 
Table 4. Pearson correlation matrix between SS, particulate and dissolved loads with hydrometeorological variables $(n=50)$ during events. Correlation is significant at the 0.01 level for bold numbers and 0.05 for italics.

\begin{tabular}{llllllllllllllll}
\hline & $P$ & $I_{\max }$ & $I_{\text {mean }}$ & $\mathrm{AP} 1 \mathrm{~d}$ & $\mathrm{AP} 3 \mathrm{~d}$ & $\mathrm{AP} 5 \mathrm{~d}$ & $\mathrm{AP} 7 \mathrm{~d}$ & $\mathrm{AP} 15 \mathrm{~d}$ & $\mathrm{AP} 21 \mathrm{~d}$ & $R$ & $Q_{\max }$ & $Q_{\mathrm{b}}$ & $Q_{\text {mean }}$ & $Q_{\mathrm{max}} / Q_{\mathrm{b}}$ & $\mathrm{SS}$ \\
\hline $\mathrm{SS}$ & $\mathbf{0 . 7 7}$ & 0.29 & 0.08 & $\mathbf{0 . 3 8}$ & $\mathbf{0 . 4 4}$ & $\mathbf{0 . 5 8}$ & $\mathbf{0 . 5 7}$ & $\mathbf{0 . 5 7}$ & $\mathbf{0 . 5 3}$ & $\mathbf{0 . 8 8}$ & $\mathbf{0 . 8 8}$ & $\mathbf{0 . 7 4}$ & $\mathbf{0 . 8 2}$ & $\mathbf{0 . 7 6}$ & 1 \\
$\mathrm{Al}$ & $\mathbf{0 . 7 5}$ & 0.26 & 0.12 & $\mathbf{0 . 4 3}$ & $\mathbf{0 . 4 5}$ & $\mathbf{0 . 5 7}$ & $\mathbf{0 . 5 6}$ & $\mathbf{0 . 5 5}$ & $\mathbf{0 . 5 2}$ & $\mathbf{0 . 8 5}$ & $\mathbf{0 . 8 5}$ & $\mathbf{0 . 7 2}$ & $\mathbf{0 . 8 0}$ & $\mathbf{0 . 7 2}$ & $\mathbf{0 . 9 8}$ \\
$\mathrm{F} \mathrm{P}_{\mathrm{P}}$ & $\mathbf{0 . 7 5}$ & 0.27 & 0.12 & $\mathbf{0 . 4 3}$ & $\mathbf{0 . 4 5}$ & $\mathbf{0 . 5 7}$ & $\mathbf{0 . 5 5}$ & $\mathbf{0 . 5 5}$ & $\mathbf{0 . 5 1}$ & $\mathbf{0 . 8 5}$ & $\mathbf{0 . 8 5}$ & $\mathbf{0 . 7 2}$ & $\mathbf{0 . 8 0}$ & $\mathbf{0 . 7 1}$ & $\mathbf{0 . 9 8}$ \\
$\mathrm{Mn}$ & $\mathbf{0 . 7 9}$ & 0.24 & 0.18 & $\mathbf{0 . 4 0}$ & $\mathbf{0 . 4 2}$ & $\mathbf{0 . 5 2}$ & $\mathbf{0 . 5 1}$ & $\mathbf{0 . 5 3}$ & $\mathbf{0 . 4 9}$ & $\mathbf{0 . 8 5}$ & $\mathbf{0 . 8 2}$ & $\mathbf{0 . 6 8}$ & $\mathbf{0 . 7 7}$ & $\mathbf{0 . 7 3}$ & $\mathbf{0 . 9 7}$ \\
$\mathrm{Cu}$ & $\mathbf{0 . 7 1}$ & 0.27 & 0.16 & $\mathbf{0 . 4 1}$ & $\mathbf{0 . 3 9}$ & $\mathbf{0 . 5 2}$ & $\mathbf{0 . 5 2}$ & $\mathbf{0 . 5 3}$ & $\mathbf{0 . 4 8}$ & $\mathbf{0 . 7 9}$ & $\mathbf{0 . 7 8}$ & $\mathbf{0 . 6 5}$ & $\mathbf{0 . 7 3}$ & $\mathbf{0 . 6 8}$ & $\mathbf{0 . 9 5}$ \\
$\mathrm{Zn}_{\mathrm{P}}$ & $\mathbf{0 . 7 3}$ & 0.23 & 0.17 & 0.32 & $\mathbf{0 . 4 5}$ & $\mathbf{0 . 5 7}$ & $\mathbf{0 . 5 7}$ & $\mathbf{0 . 5 8}$ & $\mathbf{0 . 5 4}$ & $\mathbf{0 . 8 7}$ & $\mathbf{0 . 8 6}$ & $\mathbf{0 . 7 6}$ & $\mathbf{0 . 8 3}$ & $\mathbf{0 . 6 7}$ & $\mathbf{0 . 9 3}$ \\
$\mathrm{Al} l_{\mathrm{D}}$ & $\mathbf{0 . 8 3}$ & 0.27 & 0.15 & 0.31 & $\mathbf{0 . 3 8}$ & $\mathbf{0 . 5 5}$ & $\mathbf{0 . 5 5}$ & $\mathbf{0 . 6 5}$ & $\mathbf{0 . 6 2}$ & $\mathbf{0 . 9 1}$ & $\mathbf{0 . 8 6}$ & $\mathbf{0 . 7 3}$ & $\mathbf{0 . 8 1}$ & $\mathbf{0 . 7 3}$ & $\mathbf{0 . 9 1}$ \\
$\mathrm{Fe}_{\mathrm{D}}$ & $\mathbf{0 . 7 5}$ & 0.15 & 0.30 & 0.24 & 0.25 & 0.34 & 0.33 & $\mathbf{0 . 4 8}$ & $\mathbf{0 . 4 7}$ & $\mathbf{0 . 7 6}$ & $\mathbf{0 . 6 5}$ & $\mathbf{0 . 5 2}$ & $\mathbf{0 . 6 1}$ & $\mathbf{0 . 6 2}$ & $\mathbf{0 . 7 8}$ \\
$\mathrm{Mn}_{\mathrm{D}}$ & $\mathbf{0 . 5 4}$ & 0.09 & 0.17 & 0.12 & 0.05 & 0.17 & 0.19 & 0.29 & 0.26 & $\mathbf{0 . 5 9}$ & $\mathbf{0 . 5 2}$ & $\mathbf{0 . 4 3}$ & $\mathbf{0 . 5 0}$ & $\mathbf{0 . 4 6}$ & $\mathbf{0 . 5 9}$ \\
$\mathrm{Cu}_{\mathrm{D}}$ & $\mathbf{0 . 8 0}$ & 0.24 & 0.19 & 0.30 & $\mathbf{0 . 3 7}$ & $\mathbf{0 . 5 0}$ & $\mathbf{0 . 5 0}$ & $\mathbf{0 . 6 3}$ & 0.26 & $\mathbf{0 . 9 2}$ & $\mathbf{0 . 8 4}$ & $\mathbf{0 . 7 3}$ & $\mathbf{0 . 8 0}$ & $\mathbf{0 . 6 8}$ & $\mathbf{0 . 8 6}$ \\
$\mathrm{Zn}_{\mathrm{D}}$ & $\mathbf{0 . 5 8}$ & 0.08 & 0.18 & 0.23 & 0.19 & 0.20 & 0.17 & 0.21 & 0.12 & $\mathbf{0 . 5 1}$ & $\mathbf{0 . 4 4}$ & 0.25 & $\mathbf{0 . 3 7}$ & $\mathbf{0 . 6 0}$ & $\mathbf{0 . 6 9}$ \\
\hline
\end{tabular}

Note: $\mathrm{p}$ : particulate form; $\mathrm{D}$ : dissolved form.
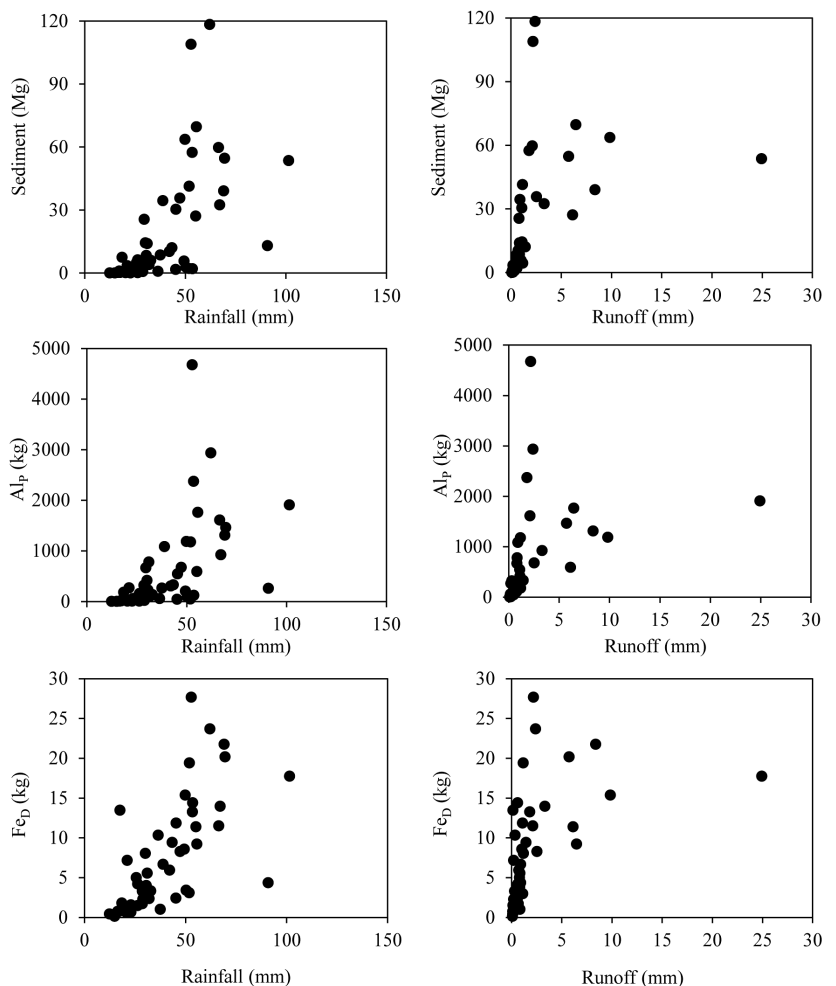

Figure 5. Relationships of rainfall and runoff with sediment, $A l_{P}$ and $\mathrm{Fe}_{\mathrm{D}}$ loads at event scale. $\mathrm{P}$ : particulate form; $\mathrm{D}$ : dissolved form.

transport capacity and consequently to sediment load. The good correlation between sediment load and runoff reflects the proportion of surface runoff which is responsible for erosion from the catchment surface. Rainfall also showed a close relationship with sediment load, suggesting that high amounts of rainfall generate high sediment amounts, as it occurs in an agroforestry catchment close to that study catchment (Rodríguez-Blanco et al., 2010b). Antecedent rainfall $1,3,5,7,15$ and 21 days before the event also affected sediment load during events through its effect on runoff and maximum discharge, since the antecedent conditions are the main factor that explains the hydrological response of the Mero catchment at event scale (Palleiro et al., 2014). The importance of antecedent conditions in runoff generation has been frequently reported in humid temperate environments with forest land use (Jordan, 1994; Rodríguez-Blanco et al., 2012). Seeger et al. (2004) related the river sedimentary response to the combination of both antecedent rainfall and amount of rainfall.

Particulate metal loads were related to the same variables as sediment load for all the studied metals, as well as to sediment load. In this catchment, the organic carbon content of the suspended matter is low because the organic carbon is mainly exported as dissolved organic carbon (data not shown), suggesting that particulate transport of metals occurs as part of the mineral fraction. The relationships with the hydrological variables were stronger than with rainfall, reflecting that the transport of particulate metals is associated with the discharge characteristics of the events, which determines particle transport capacity, and that the physical processes involved in runoff generation are determining the particulate load. Good correlations between metal loads and rainfall were also observed by Kurtenbach and Krein (2007) when metal sources were hydraulically connected to the main tributary.

Dissolved metal loads showed positive correlations with all hydrological variables, rainfall amount and sediment load. $\mathrm{Al}_{\mathrm{D}}, \mathrm{Fe}_{\mathrm{D}}$ and $\mathrm{Cu}_{\mathrm{D}}$ were also correlated with antecedent rainfall. The relationships between dissolved metals and discharge variables can be related to the washing/percolating of dissolved metals through soil and/or to the presence of microparticulate material.

Despite the large number of correlations between sediment and metal loads and hydroclimatic parameters, it was observed that there was considerable dispersion in the data. Figure 5 shows an example of the regression between rainfall 
Table 5. Derived equations for SS, particulate and dissolved metal loads applying the stepwise multiple regression technique.

\begin{tabular}{|c|c|c|c|c|}
\hline $\begin{array}{l}\text { Dependent } \\
\text { variable }\end{array}$ & Equation & $\begin{array}{l}\text { Adjusted } \\
r^{2}\end{array}$ & $\begin{array}{l}\text { Independent } \\
\text { variables }\end{array}$ & $\beta$ values \\
\hline SS & $\begin{array}{l}\mathrm{SS}=-6.1 \times 10^{-6}+1.4 Q_{\max } \\
-0.54 Q_{\mathrm{b}}\end{array}$ & 0.82 & $\begin{array}{l}Q_{\max } \\
Q_{\mathrm{b}}\end{array}$ & $\begin{array}{l}8.4 \\
-3.3\end{array}$ \\
\hline $\mathrm{Al}_{\mathrm{P}}$ & $\begin{array}{l}\mathrm{Al}_{\mathrm{P}}=-3.1 \times 10^{-3}+0.79 R \\
+0.23 \mathrm{AP} 1 \mathrm{~d}\end{array}$ & 0.77 & $\begin{array}{l}R \\
\text { AP1d }\end{array}$ & $\begin{array}{l}10.9 \\
3.2\end{array}$ \\
\hline $\mathrm{Fe}_{\mathrm{P}}$ & $\begin{array}{l}\mathrm{Fe}_{\mathrm{p}}=-1.1 \times 10^{-6}+0.79 R \\
+0.23 \mathrm{AP} 1 \mathrm{~d}\end{array}$ & 0.77 & $\begin{array}{l}R \\
\text { AP1d }\end{array}$ & $\begin{array}{l}11.0 \\
3.2\end{array}$ \\
\hline Mnp & $\begin{array}{l}\mathrm{MnP}=2.8 \times 10^{-6}+0.8 R \\
0.195 \text { AP1d }\end{array}$ & 0.76 & $\begin{array}{l}R \\
\text { AP1d }\end{array}$ & $\begin{array}{l}16.9 \\
2.7\end{array}$ \\
\hline $\mathrm{Cu}_{\mathrm{P}}$ & $\begin{array}{l}\mathrm{Cu}_{\mathrm{P}}=-1.1 \times 10^{-6}+0.73 R \\
+0.23 \mathrm{AP} 1 \mathrm{~d}\end{array}$ & 0.66 & $\begin{array}{l}R \\
\text { AP1d }\end{array}$ & $\begin{array}{l}8.3 \\
2.6\end{array}$ \\
\hline $\mathrm{Zn}_{\mathrm{P}}$ & $\begin{array}{l}\mathrm{Zn}_{\mathrm{P}}=7.0 \times 10^{-9}+0.67 Q_{\max } \\
+0.28 P\end{array}$ & 0.78 & $Q_{\max }$ & $\begin{array}{l}7.2 \\
3.0\end{array}$ \\
\hline $\mathrm{Al}_{\mathrm{D}}$ & $\begin{array}{l}\mathrm{Al}_{\mathrm{D}}=5.2 \times 10^{-6}+0.77 R \\
+0.20 Q_{\max } / Q_{\mathrm{b}}\end{array}$ & 0.84 & $\begin{array}{l}R \\
Q_{\max } / Q_{\mathrm{b}}\end{array}$ & $\begin{array}{l}9.8 \\
2.5\end{array}$ \\
\hline $\mathrm{Mn}_{\mathrm{D}}$ & $\begin{array}{l}\mathrm{Mn}_{\mathrm{D}}=2 \times 10^{-6}+1.1 Q_{\max } \\
-0.62 Q_{\mathrm{b}}\end{array}$ & 0.31 & $\begin{array}{l}Q_{\max } \\
Q_{\mathrm{b}}\end{array}$ & $\begin{array}{l}3.4 \\
-2.0\end{array}$ \\
\hline
\end{tabular}

Note: $\mathrm{p}$ : particulate form; $\mathrm{D}$ : dissolved form

and runoff with sediment and metal loads. It can be seen that rainfall of about $53 \mathrm{~mm}$ may be related to loads ranging from 2 to $109 \mathrm{Mg}$ of SS (sediment), from 47 to $4671 \mathrm{~kg}$ of $\mathrm{Al}_{\mathrm{P}}$ and from 2 to $28 \mathrm{~kg}$ of $\mathrm{Fe}_{\mathrm{D}}$. For runoff of $2.2 \mathrm{~mm} \mathrm{SS}, \mathrm{Al}_{\mathrm{P}}$ and $\mathrm{Fe}_{\mathrm{D}}$ loads were reported oscillating between 60 and $109 \mathrm{Mg}$, between 1610 and $4671 \mathrm{~kg}$ and between 12 and $28 \mathrm{~kg}$, respectively.

In order to know the combined effect of several hydroclimatic factors on the variability of the sediment and metal load, a stepwise multiple regression was carried out (Table 5) considering the set of hydroclimatic factors that showed significant correlations with the load (Table 4). It was found that the combined effect of $Q_{\max }$ and $Q_{\mathrm{b}}$ slightly improved the variability explained for sediment load. All particulate metal loads, except $\mathrm{Zn}_{\mathrm{P}}$, were governed by runoff and AP1d. The $\mathrm{Zn}_{\mathrm{P}}$ load can be explained by both $Q_{\max }$ and rainfall. With regard to dissolved metal loads, the $\mathrm{Al}_{\mathrm{D}}$ load was influenced by runoff and $Q_{\max } / Q_{\mathrm{b}}$. The $\mathrm{Mn}_{\mathrm{D}}$ load can be explained by $Q_{\max }$ and $Q_{\mathrm{b}}$. Finally, with regard to $\mathrm{Fe}_{\mathrm{D}}, \mathrm{Cu}_{\mathrm{D}}$ and $\mathrm{Zn}_{\mathrm{D}}$, the use of complex models does not provide additional information to the simple-regression technique; thereby, rejecting the use of multiple regressions to detect the possible influence of hydroclimatic variables on these elements.

The fact that hydrometeorological variables did not explain all the variability in sediment and metal loads could be because other factors such as the different particulate sources, i.e., soil erosion, particulate resuspension into the channel, among others, can affect particulate metal loads, as demonstrated by Kurtenbach and Krein (2007) when analyzing natural and artificial events.

\section{Conclusions}

Interannual variability in sediment, particulate and dissolved metal loads was observed in the study catchment. Sediment and particulate metal loads followed the same trend as streamflow, while dissolved metals showed different patterns. Only the $\mathrm{Al}_{\mathrm{D}}$ load increased with streamflow, indicating runoff is a pathway of $\mathrm{Al}_{\mathrm{D}}$ while $\mathrm{Fe}_{\mathrm{D}}$ and $\mathrm{Mn}_{\mathrm{D}}$ loads were higher in the driest year, probably due to their presence in groundwater.

Different seasonal patterns of sediment and particulate metal loads were also observed during these 3 hydrological years according to different rainfall and streamflow distribution; in spite of that, summer months always showed the lowest sediments and particulate metal export. In dissolved form, only $\mathrm{Al}_{\mathrm{D}}$ and $\mathrm{Cu}_{\mathrm{D}}$ behaved as their particulate forms, while $\mathrm{Fe}_{\mathrm{D}}, \mathrm{Mn}_{\mathrm{D}}$ and $\mathrm{Zn} \mathrm{n}_{\mathrm{D}}$ did not show any seasonal patterns or some relationship with rainfall and streamflow.

The contribution from events to total exportation was higher than from the baseflow for all particulate metals, except $\mathrm{Zn}_{\mathrm{P}}$. Baseflow was the major contributor to dissolved loads. The rainfall-runoff-event exportation was characterized by a wide variability of metal loads. The effect of one single runoff event on the annual metal load was observed especially for $\mathrm{Mn}_{\mathrm{D}}$. A few events $(30 \%)$ were responsible for 
almost $80 \%$ of the sediment, particulate and dissolved metal loads exported during events. The metal load was dominated by its particulate form.

Particulate metal loads were highly related to sediment load, indicating that in the study catchment particulate metal load may be estimated by sediment load. $Q_{\max }$ and, to a lesser extent, $Q_{\mathrm{b}}$ (a proxy of antecedent moisture conditions of the catchment) were the hydroclimatic factors governing the sediment and $\mathrm{Mn}_{\mathrm{D}}$ loads at the event scale in the Mero catchment, while runoff was the main factor controlling particulate metal loads, except for $\mathrm{Zn}_{\mathrm{P}}$ which was regulated by $Q_{\max }$. $\mathrm{Al}_{\mathrm{D}}$ was influenced by runoff and $Q_{\max } / Q_{\mathrm{b}}$.

The obtained results reveal that a substantial fraction of metals was associated with sediments, suggesting that sedimentation within the catchment might be an appropriate management practice for reducing the metal load generated in the Mero River. In addition, this study reiterates the necessity for knowledge of metal loads under different hydrological conditions because hydrological changes may cause peaks of critical loads.

Acknowledgements. This investigation was carried out within the projects REN2003-08143, funded by the Spanish Ministry of Education and Science, and PGIDIT05RAG10303PR and 10MDS103031, financed by Xunta of Galicia. The first author was awarded a predoctoral fellowship from the University of A Coruña and the second a postdoctoral research contract (Xunta of Galicia).

Edited by: P. Grathwohl

\section{References}

Adriano, D. C.: Trace elements in terrestrial environments, Biogeochemistry, bioavailability and risks of metals, 2nd Edn. Springer, New York, 2001.

Aldrich, A. P., Kistler, D., and Sigg, L.: Speciation of $\mathrm{Cu}$ and $\mathrm{Zn}$ in drainage water from agricultural soils, Environ. Sci. Technol., 36, 4824-4830, 2002.

Álvarez-Iglesias, P., Rubio, B., and Pérez-Arlucea, M.: Reliability of subtidal sediments as "geochemical recorders" of pollution input: San Simón Bay (Ría de Vigo, NW Spain), Estuar. Coast. Shelf S., 70, 507-521, 2006.

Arnold, J. G., Allen, P. M., Muttiah, R., and Bernhardt, G.: Automated base flow separation and recession analysis techniques, Ground Water, 33, 1010-1018, 1995.

Borg, H. and Johansson, K.: Metal fluxes to Swedish forest lakes, Water Air Soil Pollut., 47, 427-440, 1989.

Bull, L. J.: Magnitude and variation in the contribution of bank erosion to the suspended sediment load of the river Severn, UK, Earth Surf. Proc. Land., 22, 1109-1123, 1997.

Cánovas, C. R., Hubbard, C. G., Olías, M., Nieto, J. M., Black, S., and Coleman, M. L.: Hydrochemical variations and contaminant load in the Río Tinto (Spain) during flood events, J. Hydrol., 250, 25-40, 2008.

Devesa-Rey, R., Díaz-Fierros, F., and Barral, M. T.: Assessment of enrichment factors and grain size influence on the metal distribu- tion in riverbed sediments (Anllóns River, NW Spain), Environ. Monit. Assess., 179, 371-388, 2011.

Exley, C.: A biogeochemical cycle for aluminium, J. Inorg. Biochem., 97, 1-7, 2003.

FAO: World reference base for soil resources, Rome, Italy, 2006.

Förstner, U. and Wittmann, T. W.: Heavy metal pollution in the aquatic environment, 2nd Edn. Spring-Verlag, Berlin, 1981.

Guitián Ojea, F., Guitián Rivera, F., Barral Silva, M. T., Conde Pumpido, R., and Núñez Cardezo, A.: Atlas geoquímico de Galicia, Xunta de Galicia, Santiago, 1992.

Horowitz, A. J., Rinella, F. A., Lamothe, P., Miller, T. L., Edwards, T. K., Roche, R. L., and Rickert, D. A.: Variations in Suspended Sediment and Associated Trace Element Concentrations in Selected Riverine Cross Sections, Environ. Sci. Technol., 24, 13131320, 1990.

Jordan, J. P.: Spatial and temporal variability of stormflow generation processes on a Swiss catchment, J. Hydrol., 153, 357-382, 1994.

Kang, J. H., Lee, Y. S., Ki, S. J., Lee, Y. G., Cha, S. M., Cho, K. H., and Kim, J. H.: Characteristics of wet and dry weather heavy metal discharges in the Yeongsan Watershed, Korea, Sci. Total Environ., 407, 3482-3493, 2009.

Kurtenbach, A. and Krein, A.: Pre-event hydrological conditions as determinants for suspended sediment and pollutant transport during artificial and natural floods, in: Sediment dynamics and pollutant mobility in rivers: an Interdisciplinary Approach, edited by: Westrich, B. and Forster, U., Springer, Berlin, Heidelberg, 279-287, 2007.

L'Herroux, L., Le Roux, S., Appriou, P., and Martínez, J.: Behaviour of metals following intensive pig slurry applications to a natural field treatment process in Brittany (France), Environ. Pollut., 97, 119-130, 1997.

McPherson, T. N., Burian, S. J., Stenstrom, M. K., Turin, H. J., Brown, M. J., and Suffet, I. H.: Trace metal pollutant load in urban runoff from a southern California watershed, J. Environ. Eng.-ASCE, 131, 1073-1080, 2005.

Miller, C. V., Foster, G. D., and Majedi, B. F.: Baseflow and stormflow metal fluxes from two small agricultural catchments in the Coastal Plain of the Chesapeake Bay Basin, US, Appl. Geochem., 18, 483-501, 2003.

Nagano, T., Yanase, N., Tsuduki, K., and Nagao, S.: Particulate and dissolved elemental loads in the Kuji River related to discharge rate, Environ. Int., 28, 649-658, 2003.

Navrátil, T., Sjanley, J. B., Skřivan, P., Krám, P., Mihaljevič, M., and Drahota, P.: Manganese biogeochemistry in a Central Czech Republic catchment, Water Air Soil Pollut., 186, 149-165, 2007.

Ollivier, P., Radakovitch, O., and Hamenlin, B.: Major and trace partition and fluxes in the Rhône River, Chem. Geol., 285, 1531, 2011.

Palleiro, L., Rodríguez-Blanco, M. L., Taboada-Castro, M. M., and Taboada-Castro, M. T.: Dissolved and particulate metals in the Mero River (NW Spain): Factors affecting concentrations and load during runoff events, Commun. Soil Sci. Plan., 49, 88-94, 2012.

Palleiro, L., Rodríguez-Blanco, M. L., Taboada-Castro, M. M., and Taboada-Castro, M. T.: Hydrological response of a humid agroforestry catchment at different time scales, Hydrol. Process., 28, 1677-1688, 2014. 
Park, J. H., Lee, J. H., Kang, S. Y., and Kim, S. Y.: Hydroclimatic control on dissolved organic matter (DOM) characteristics and implications for trace metal transport in Hwangryong River Watershed, Korea, during a summer monsoon period, Hydrol. Process., 21, 3025-3034, 2007.

Pokrovsky, O. S., Viers, J., Shirikova, L. S., Shevchenko, V. P., Filipov, A. S., and Dupre, B.: Dissolved, suspended, and colloidal fluxes of organic carbon, major and trace elements in the Severnaya Dvina River and its tributary, Chem. Geol., 273, 136-149, 2010.

Rodríguez-Blanco, M. L., Taboada-Castro, M. M., Diéguez-Villar, A., and Taboada-Castro, M. T.: Metal fluxes from soils to surface waters at catchment scale, Commun. Soil Sci. Plan., 40, 313326, 2009

Rodríguez-Blanco, M. L., Taboada-Castro, M. M., Palleiro, L., and Taboada-Castro M. T.: Temporal changes in suspended sediment transport in an Atlantic catchment, NW Spain, Geomorphology, 123, 181-188, 2010a.

Rodríguez-Blanco, M. L., Taboada-Castro, M. M., and TaboadaCastro, M. T.: Factors controlling hydro-sedimentary response during runoff events in a rural catchment in the humid Spanish zone, Catena, 82, 206-217, 2010b.

Rodríguez-Blanco, M. L., Taboada-Castro, M. M., and TaboadaCastro, M. T.: Sources and sediment yield from a rural catchment in humid temperate environment, NW Spain, Earth Surf. Proc. Land., 35, 272-277, 2010c.

Rodríguez-Blanco, M. L., Taboada-Castro, M. M., and TaboadaCastro, M. T.: Rainfall-runoff response and event-based runoff coefficients in a humid area (northwest Spain), Hydrolog. Sci. J., 57, 444-459, 2012.

Rodríguez-Blanco, M. L., Taboada-Castro, M. M., and TaboadaCastro, M. T.: Linking the field to the stream: Soil erosion and sediment yield in a rural catchment, NW Spain, Catena, 102, 7481, 2013.

Seeger, M., Erreas, M. P., Beguería, S., Arnáez, J., Martí, C., and García-Ruíz, J. M.: Catchment soil moisture and rainfall characteristics as determinant factors for discharge/suspended sediment hysteretic loops in a small headwater catchment in the Spanish Pyrenees, J. Hydrol., 288, 299-311, 2004.
Sigg, L., Xue, H., Kistler, D., and Schönenberger, R.: Size fractionation (dissolved, colloidal and particulate) of trace metals in the Thur River, Switzerland, Aquat. Geochem., 6, 413-434, 2000.

Soto-Varela, F., Rodríguez-Blanco, M. L., Taboada-Castro, M. M., and Taboada-Castro, M. T.: Metals discharged during different flow conditions from a mixed agricultural-forest catchment (NW Spain), Hydrol. Process., online first, doi:10.1002/hyp.10282, 2014a.

Soto-Varela, F., Rodríguez-Blanco, M. L., Taboada-Castro, M. M., and Taboada-Castro, M. T.: Identifying environmental and geochemical variables governing metal concentrations in a stream draining headwaters in NW Spain, Appl. Geochem., 44, 61-68, 2014b.

Taboada-Castro, M. M., Diéguez-Villar, A., and Taboada-Castro, M. T.: Effect of soil use and agricultural practices on heavy metal levels in surface waters, Commun. Soil Sci. Plan., 33, 2933 2849, 2002.

Taboada-Castro, M. M., Rodríguez-Blanco, M. L., Palleiro, L., and Taboada-Castro, M. M.: Importancia de la cubierta vegetal en procesos de erosión por flujo concentrado en ambiente templado húmedo: un estudio a escala de cuenca, IV Congreso Ibérico de la Ciencia del Suelo, 21-24 September, Granada, Spain, 2010.

Taboada-Castro, M. M., Diéguez-Villar, A., Rodríguez-Blanco, M. L., and Taboada-Castro, M. T.: Agricultural impact of dissolved trace elements in runoff water from an experimental catchment with land-use changes, Commun. Soil Sci. Plan., 43, 81-87, 2012.

Walling, D. E, Webb, B. W., and Russell, M. A.: Sedimentassociated nutrient transport in UK rivers, Freshwater Contamination, in: Proceedings of Rabat Symposium S4, April-May 1997, Rabat, Morocco, 69-81, 1997.

Xue, H., Sigg, L., and Gächter, R.: Transport of $\mathrm{Cu}, \mathrm{Zn}$ and $\mathrm{Cd}$ in a small agricultural catchment, Water Res., 34, 2558-2568, 2000. 